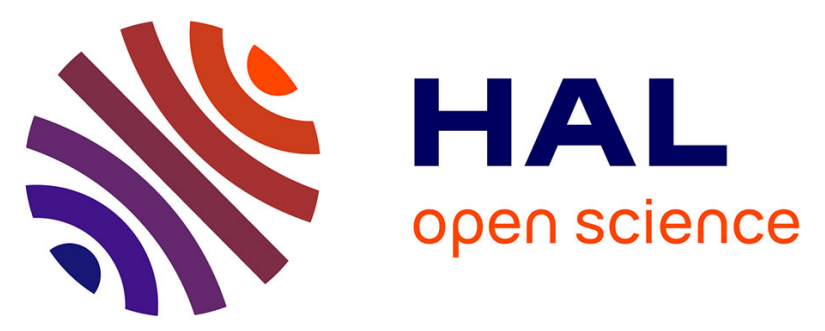

\title{
Effect of digestive enzymes on antimicrobial, radical scavenging and angiotensin I-converting enzyme inhibitory activities of camel colostrum and milk proteins
}

Zeineb Jrad, Halima El Hatmi, Isabelle Adt, Jean-Michel Girardet, Céline Cakir-Kiefer, Julien Jardin, Pascal Degraeve, Touhami Khorchani, Nadia Oulahal

\section{- To cite this version:}

Zeineb Jrad, Halima El Hatmi, Isabelle Adt, Jean-Michel Girardet, Céline Cakir-Kiefer, et al.. Effect of digestive enzymes on antimicrobial, radical scavenging and angiotensin I-converting enzyme inhibitory activities of camel colostrum and milk proteins. Dairy Science \& Technology, 2014, 94, pp.205-224. 10.1007/s13594-013-0154-1 . hal-01209601

\section{HAL Id: hal-01209601 https://hal.science/hal-01209601}

Submitted on 28 May 2020

HAL is a multi-disciplinary open access archive for the deposit and dissemination of scientific research documents, whether they are published or not. The documents may come from teaching and research institutions in France or abroad, or from public or private research centers.
L'archive ouverte pluridisciplinaire HAL, est destinée au dépôt et à la diffusion de documents scientifiques de niveau recherche, publiés ou non, émanant des établissements d'enseignement et de recherche français ou étrangers, des laboratoires publics ou privés. 


\title{
Effect of digestive enzymes on antimicrobial, radical scavenging and angiotensin I-converting enzyme inhibitory activities of camel colostrum and milk proteins
}

\author{
Zeineb Jrad • Halima EI Hatmi • Isabelle Adt • Jean-Michel Girardet • \\ Céline Cakir-Kiefer • Julien Jardin • Pascal Degraeve • \\ Touhami Khorchani • Nadia Oulahal
}

Received: 26 April 2013 /Revised: 9 October 2013 / Accepted: 11 October 2013 /

Published online: 20 December 2013

(C) INRA and Springer-Verlag France 2013

\begin{abstract}
Camel milk and colostrum are known to be a rich source of bioactive proteins. Camel milk, colostrum and colostral whey proteins were successively hydrolysed by pepsin and pancreatin using an in vitro protocol mimicking gastro-intestinal digestion. The degradation of proteins was characterised by electrophoresis and reversed-phase ultra-high performance liquid chromatography. Two whey proteins, $\alpha$-lactalbumin and immunoglobulins $\mathrm{G}$, were more resistant to the digestive proteolytic enzymes than other camel milk and colostrum proteins. Undigested and digested samples were assayed for their antioxidant, angiotensin I-converting enzyme inhibitory and antimicrobial
\end{abstract}

Z. Jrad $\cdot$ H. El Hatmi $\cdot$ T. Khorchani

Laboratoire d'Elevage et Faune Sauvage, Institut des Régions Arides de Médenine, Médenine, Tunisia

Z. Jrad $\cdot$ H. El Hatmi $(\bowtie)$

Université de Gabes, Département agro-alimentaire, Institut Supérieur de Biologie Appliquée de Médenine, Gabes, Tunisia

e-mail: halima.elhatmi@ira.rnrt.tn

I. Adt $\cdot$ P. Degraeve $\cdot$ N. Oulahal

Université Lyon 1, BioDyMIA* (Bioingénierie et Dynamique Microbienne aux Interfaces Alimentaires) Equipe Mixte d’Accueil n`3733 ISARA Lyon, Université de Lyon, Technopole Alimentec — rue Henri de Boissieu, Bourg en Bresse 01000 France

J.-M. Girardet • C. Cakir-Kiefer

Université de Lorraine, UR AFPA (Unité de Recherche Animal et Fonctionnalités des Produits Animaux), Equipe PB2P (Protéolyse \& Biofonctionnalités des Protéines et des Peptides),

Vandœuvre-lès-Nancy 54506 France

J.-M. Girardet • C. Cakir-Kiefer

INRA, UR AFPA Unité Sous Contrat 340, Vandœuvre-lès-Nancy 54506 France

J. Jardin

INRA, UMR1253 Science et Technologie du Lait et de l'CEuf, 35042 Rennes, France

J. Jardin

Agrocampus Ouest, UMR1253 Science et Technologie du Lait et de l'EEuf, 35042 Rennes, France

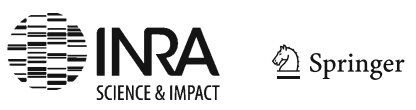


properties. Camel colostrum, colostral whey and milk proteins had unveiled angiotensin I-converting enzyme (ACE) inhibitory activity following in vitro enzymatic digestion and a higher free radical scavenging activity than before their digestion. Moreover, Escherichia coli XL1 blue and Listeria innocua LRGIA01 cells growth were both inhibited by undigested and digested samples, suggesting that antimicrobial proteins resisted to the action of digestive enzymes or that antimicrobial fragments of camel milk and colostrum proteins were released or both. After pepsin and pancreatin hydrolysis, camel milk and colostrum proteins digests still had an antibacterial activity and their antioxidative and ACE-inhibitory activity even increased, suggesting that bioactive fragments of camel milk and colostrum proteins such as antioxidative and ACEinhibitory peptides were released. Among 181 peptides identified by tandem mass spectrometry, 25 were homologous to known bioactive peptides, particularly with ACE inhibitors and free radical scavengers.

Keywords Angiotensin I-converting enzyme inhibition · Antibacterial activity · Antioxidant activity Camel colostrum proteins $\cdot$ Camel milk proteins $\cdot$ Digestive enzymes

\section{Introduction}

Besides providing essential amino acids, colostrum and to a lesser extent milk proteins can exhibit different biological activities (Korhonen and Pihlanto 2007). For instance, lactoferrin (Lf) present in the milk or colostrum of various species of mammals exerts antimicrobial activities (Farnaud and Evans 2003). Camel milk and colostrum protein composition and structure have been reported to differ from those of milk and colostrum proteins of the other mammals (Farah 1993; El Hatmi 2007). These differences mainly concern whey proteins: for example $\beta$-lactoglobulin $(\beta-L G)$, the main bovine whey protein, is absent from camel whey, while cow's milk is deficient in some camel milk proteins such as peptidoglycan recognition protein (PGRP; Kappeler et al. 2004) and camel whey basic protein (CWBP; Ochirkhuyag et al. 1998). Moreover, according to Abd El-Gawad et al. (1996), the concentration of Lf in camel milk (0.34 g.L $\left.\mathrm{L}^{-1}\right)$ and colostrum (5.10 g. $\mathrm{L}^{-1}$ at the second day after parturition) has been reported to be higher than in its bovine counterparts $\left(0.06\right.$ g.L ${ }^{-1}$ in milk and 0.50 g.L $\mathrm{L}^{-1}$ in colostrum at the second day after parturition). Camel milk is a rich source of proteins with potential antimicrobial and antioxidative activities (Salami et al. 2010). As it is the main diet of some desert nomads and as the latter use it in traditional medicine for the treatment of gastric problems, the biological activities of the proteins deserve further study. Some prerequisites have to be considered: (1) a bioactive protein might have an effect on the health of its consumers once ingested and its biological activity should not be impaired following its hydrolysis by digestive proteolytic enzymes, or (2) a protein might possess biologically active regions encrypted in its sequence that should be liberated by the digestive enzymes.

Numerous authors have thus reported that peptides inhibiting the angiotensin Iconverting enzyme (ACE; EC 3.4.15.1) in vitro can be released from the milk proteins by digestive proteolytic enzymes (Hernandez-Ledesma et al. 2004; Jäkälä and Vapaalo 2010; Ricci et al. 2010; Rousseau-Ralliard et al. 2011; Qureshi et al. 2013). Interestingly, as ACE is a peptidyl carboxydipeptidase which catalyses the production 
of the vasoconstrictor angiotensin II and the inactivation of the vasodilator bradykinin, molecules significantly inhibiting its activity can exert an antihypertensive activity in vivo, although it is clear that a significant inhibition of ACE in vitro does not warrant any antihypertensive effect in vivo (Hernández-Ledesma et al. 2011). Recently, Salami et al. (2011) reported that ACE-inhibitory peptides were released following the successive actions of pepsin and trypsin, or chymotrypsin on camel whole casein $(\mathrm{CN})$. Salami et al. (2010) also reported that the antioxidative and the antimicrobial activities of camel milk whey proteins can be increased after a limited proteolysis by trypsin or chymotrypsin.

However, to our knowledge, biological activities such as radical scavenging and ACE-inhibitory activities of camel colostrum proteins have never been studied neither before, nor after enzymatic digestion. Therefore, the effect of the action of pepsin and then pancreatin (to mimic the gastric and intestinal phases of digestion, respectively) on camel (Camelus dromedarius) colostrum (CP), colostral whey (CWP) and milk proteins (MP) on their antioxidative, ACE-inhibitory and antibacterial activities were investigated in the present study. Identification of peptides released by the action of the digestive enzymes was performed by tandem mass spectrometry, and some peptides with putative biological activity were found by sequence alignment with known bioactive peptides.

\section{Materials and methods}

\subsection{Samples collection}

Colostrum and milk were obtained from five healthy dromedaries ( $C$. dromedarius) all belonging to the experimental herd of the Livestock and Wildlife Laboratory (Institute of Arid Land, Medenine, Tunisia). Colostrum samples were collected from $1 \mathrm{~h}$ to $144 \mathrm{~h}$ post-partum and analysed by sodium dodecyl sulphate-polyacrylamide gel electrophoresis (SDS-PAGE) to determine which sample contained the highest content of Lf, the main antimicrobial protein. Camel milks were collected between the second and fourth week post-partum and mixed. All samples, collected manually in sterile bottles once per day (usually in the morning), were divided into three aliquots and were immediately stored at $-20{ }^{\circ} \mathrm{C}$ until used.

\subsection{Whey protein and casein separation}

Colostral whey proteins (CWP) were prepared as described in a previous work for milk whey protein preparation (El Hatmi et al. 2007) with some modifications. Camel colostrum was skimmed by centrifugation $\left(5,000 \times \mathrm{g}, 30 \mathrm{~min}, 4{ }^{\circ} \mathrm{C}\right)$ and warmed at $30{ }^{\circ} \mathrm{C}$ (the camel milk was also skimmed with the same experimental conditions). Caseins were separated from whey proteins following $\mathrm{pH}$ adjustment to 4.2 with 1 mol. $\mathrm{L}^{-1} \mathrm{HCl}$ to enhance their precipitation. After a centrifugation at $5,000 \times \mathrm{g}$ for $30 \mathrm{~min}$ at $20{ }^{\circ} \mathrm{C}$, CWP (supernatant) were neutralised by $1 \mathrm{~mol} \cdot \mathrm{L}^{-1} \mathrm{NaOH}$ before dialysis (cut-off of dialysis membranes $=100-500$ Da, SpectraPor; Spectrum Labs Inc., Rancho Dominguez, CA, USA) against 200 vol of distilled water for $72 \mathrm{~h}$ and freezedried before use. 


\subsection{In vitro digestion}

All samples were in vitro digested by the simplified procedure described by Parrot et al. (2003). For the gastric digestion step, $20 \mathrm{mg}$ of freeze-dried samples, i.e. MP, CWP and $\mathrm{CP}$, were dissolved in $1 \mathrm{~mL}$ of ultra-pure (Milli-Q) water (Millipore, Bedford, MA, USA). The $\mathrm{pH}$ was adjusted to 2.0 with $1 \mathrm{~mol} . \mathrm{L}^{-1} \mathrm{HCl}$. Pepsin (EC 3.4.23.1) at $1 \mathrm{~g} . \mathrm{L}^{-1}$ in $0.01 \mathrm{~mol} . \mathrm{L}^{-1} \mathrm{HCl}$ [from porcine stomach mucosa; specific activity of 3260 units (U). $\mathrm{mg}^{-1}$ protein; Sigma-Aldrich Co., St. Louis, MO, USA] was added at an enzymeto-substrate mass ratio of 1:200. The digestion was performed at $37^{\circ} \mathrm{C}$ for $30 \mathrm{~min}$. To mimic the intestinal digestion step, the $\mathrm{pH}$ was increased to 7.5 with $30 \% \mathrm{w} / \mathrm{w} \mathrm{NaOH}$ added dropwise to simulate the $\mathrm{pH}$ in the duodenum. Twenty-five microliters of pancreatin at 2 g.L $\mathrm{L}^{-1}$ in water (from bovine pancreas, activity equivalent to 8 U.S.P. specifications according to the supplier Sigma-Aldrich) was added to $975 \mu \mathrm{L}$ of peptic digest to get an enzyme-to-substrate mass ratio of 1:400. Simulated intestinal digestion of samples was carried out at $37^{\circ} \mathrm{C}$ for $4 \mathrm{~h}$. Then, the protein hydrolysis reaction was stopped by heating at $85^{\circ} \mathrm{C}$ for $5 \mathrm{~min}$. Digested samples were directly stored at $-20^{\circ} \mathrm{C}$ until analysed, while samples for antimicrobial activity assays were dialysed (cut-off of dialysis membranes $=100-500 \mathrm{~g} \cdot \mathrm{mol}^{-1}$ ) for $48 \mathrm{~h}$ against $200 \mathrm{vol}$ of Milli-Q water and freeze-dried prior to storage at $-20{ }^{\circ} \mathrm{C}$.

\subsection{SDS-PAGE analysis}

The protein composition of the different fractions was determined by SDS-PAGE according to Laemmli and Favre (1973). SDS-PAGE was running in $4.9 \% \mathrm{w} / \mathrm{v}$ polyacrylamide stacking gel at $\mathrm{pH} 6.8$ and in $15.4 \% \mathrm{w} / \mathrm{v}$ polyacrylamide resolving gel at $\mathrm{pH} 8.8$. Samples were dissolved in 0.125 mol. $\mathrm{L}^{-1}$ tris(hydroxymethyl)aminomethane (Tris)-HCl buffer, $\mathrm{pH} 6.8$, in the presence of $0.1 \% \mathrm{w} / \mathrm{v}$ SDS, $5 \% \mathrm{v} / \mathrm{v} 2-$ mercaptoethanol, $10 \% \mathrm{v} / \mathrm{v}$ glycerol, and $0.01 \% \mathrm{w} / \mathrm{v}$ bromophenol blue. Volumes of $30 \mu \mathrm{L}$ of samples $\left(2 \mathrm{~g} . \mathrm{L}^{-1}\right)$ were loaded on the gel and the protein bands were stained by Coomassie Brilliant Blue R-250. Precision Plus Protein Prestained All Blue Standards (Bio-Rad, Hercules, CA, USA) were used as molecular mass standards.

\subsection{Protein and peptide quantification}

The protein concentration was determined in triplicates by the Bradford method using bovine serum albumin (BSA) as protein standard (Ku et al. 2013) and the data are expressed as milligrams per liter equivalent (eq.) to BSA.

The peptide concentration in different hydrolysates samples was estimated by using the $o$-phthaldialdehyde (OPA) method of Frister et al. (1988). The OPA solution was prepared as follows: $100 \mathrm{mmol} . \mathrm{L}^{-1}$ sodium tetrahydroborate buffer, $\mathrm{pH} 9.3$, containing $1 \% \mathrm{w} / \mathrm{v}$ SDS, 6 mmol.L $\mathrm{L}^{-1} \mathrm{OPA}$ (dissolved in an aliquot of pure methanol), and $14 \mathrm{mmol} . \mathrm{L}^{-1}$ of $2-$ mercaptoethanol. A quantity of $3 \mathrm{mg}$ of freeze-dried powder was dissolved in $1 \mathrm{~mL}$ of water and aliquots of $20 \mu \mathrm{L}$ were mixed to $200 \mu \mathrm{L}$ of OPA reagent. The solutions were mixed briefly and their absorbance at $340 \mathrm{~nm}$ was measured after a 3-min reaction time at room temperature using an $\mathrm{MRX}^{\circledR}$ microplate reader (ThermoLabsystems, Chantilly, VA, USA). Calibration curve was established with leucine. The concentration was expressed in micromoles per liter eq. $\mathrm{NH}_{2}$. All the assays were carried out in triplicates. 


\subsection{Reversed phase ultra-high performance liquid chromatography (RP-UHPLC)}

The protein fractions and their corresponding hydrolysates $\left(1 \mathrm{mg} \cdot \mathrm{mL}^{-1}\right.$ of freeze-dried sample) were analysed by RP-UHPLC. Volumes of $10 \mu \mathrm{L}$ were loaded onto a XB-C18 analytical column (150-mm length, internal diameter of $2.1 \mathrm{~mm}, 2.6-\mu \mathrm{m}$ particle size, 10-nm porosity; Phenomenex, Le Pecq, France) connected to a UHPLC system (Shimadzu, France) equipped with a photodiode array detector SPD M20A and a gradient pump LC 30AD. Peptides were then eluted for $90 \mathrm{~min}$ by a linear gradient from 5 to $50 \% \mathrm{v} / \mathrm{v}$ acetonitrile in water and in the presence of $0.1 \% \mathrm{v} / \mathrm{v}$ trifluoroacetic acid (TFA) at $27{ }^{\circ} \mathrm{C}$. The flow rate was $0.5 \mathrm{~mL} \cdot \mathrm{min}^{-1}$, detection was carried out at $215 \mathrm{~nm}$ and the separation was analysed with the LabSolutions version 4.2 software (Shimadzu).

2.7 Nano-electrospray ionisation tandem mass spectrometry coupled with liquid chromatography (LC/nESI-MS/MS)

Peptide hydrolysate was analysed by on-line LC/nESI-MS/MS on a nanoLC Dionex RSLC system coupled to a ThermoScientific Q Exactive Quadrupole-Orbitrap mass spectrometer (Dionex/ThermoScientific, Villebon-sur-Yvette, France). A quantity of $0.3 \mu \mathrm{g}(10 \mu \mathrm{L})$ was loaded onto a RP-HPLC C18 Acclaim PepMap100 column (150$\mathrm{mm}$ length, internal diameter of $75 \mu \mathrm{m}, 3-\mu \mathrm{m}$ particle size, 10-nm porosity; Dionex/ThermoScientific). Chromatographic separation was performed with a linear gradient of 4 to $60 \% \mathrm{v} / \mathrm{v}$ acetonitrile in water in the presence of $0.08 \% \mathrm{v} / \mathrm{v}$ formic acid and $0.1 \% \mathrm{v} / \mathrm{v}$ TFA for $50 \mathrm{~min}$ at a flow rate of $0.3 \mu \mathrm{L} \cdot \mathrm{min}^{-1}$. Ionization of peptides by a Proxeon ESI source was performed in positive mode at a voltage of $2 \mathrm{kV}$. Each MS spectrum was acquired over the range of $\mathrm{m} / \mathrm{z}$ values from 300 to 2,000 and MS/MS fragmentation was performed on the 10 most intense ions.

Peptides were identified from MS/MS spectra using X!Tandem pipeline software (Plateforme d'Analyse Protéomique de Paris Sud-Ouest, INRA, Jouy-en-Josas, France, http://pappso.inra.fr). The peptide identification database was composed of the Camelus taxonomy ( $\left.{ }^{\circ} 9836\right)$ downloaded from www.uniprot.org on the 13th of August 2013. Database search parameters were specified as follows: an unspecific enzyme cleavage was selected; a 0.05-Da mass error was allowed on fragment ions while $10 \mathrm{ppm}$ mass error was allowed for parent ions; phosphorylation of serine was selected as a variable modification; and for each peptide identified, a minimum score corresponding to an e-value below 0.05 was considered to be a prerequisite for valid peptide identification.

Sequence alignments with known peptides displaying any biological activity were performed with the PepBank database available on http://pepbank.mgh.harvard.edu/ search/blast.

\subsection{Radical scavenging activity measurements}

The free radical scavenging activity of gallic acid and Trolox as well as proteins and peptides was carried out according to the method of Re et al. (1999) adapted to small reaction volumes by Sadat et al. (2011). Briefly, the ABTS $^{+}$(ABTS-2,2'azino-bis(3-ethylbenzothiazoline-6-sulphonic acid)) radical cation was produced by 
dissolving $7 \mathrm{mmol} . \mathrm{L}^{-1}$ of cation $\mathrm{ABTS}^{+}$in $2.45 \mathrm{mmol} . \mathrm{L}^{-1}$ potassium persulfate and keeping the mixture in the dark for $15 \mathrm{~h}$ at room temperature. The $\mathrm{ABTS}^{+\bullet}$ radical cation reagent was then diluted with $5 \mathrm{mmol} . \mathrm{L}^{-1}$ sodium phosphate buffer, $\mathrm{pH} 7.4$ to reach an absorbance of ca. 0.7 at $740 \mathrm{~nm}$. The radical was stable for at least $1 \mathrm{~h}$ at $22{ }^{\circ} \mathrm{C}$. Gallic acid, Trolox, and the protein and peptide fractions were dissolved in $150 \mu \mathrm{L}$ of a solution of $20 \% \mathrm{v} / \mathrm{v}$ acetonitrile in water and added to $150 \mu \mathrm{L}$ of the $\mathrm{ABTS}^{+}$radical reagent, and incubated for $10 \mathrm{~min}$ at $30{ }^{\circ} \mathrm{C}$, then absorbance was measured at $740 \mathrm{~nm}$ with an $\mathrm{MRX}^{\circledR}$ microplate reader as a function of concentration. All the experimental points of the curves of the radical scavenging activity versus the proteins or peptides concentration were mean values of five measurements $\pm \mathrm{SD}$ (standard deviation). The antioxidant activity was calculated as follows:

$$
\operatorname{Activity}(\%)=\left[1-\left(A_{\mathrm{r}}-A_{\mathrm{b}}\right) /\left(A_{\mathrm{i}}-A_{\mathrm{b}}\right)\right] \times 100
$$

where $A_{\mathrm{i}}$ is the absorbance of the initial $\mathrm{ABTS}^{+\bullet}$ radical cation, $A_{\mathrm{r}}$ is the absorbance of the remaining radical and $A_{\mathrm{b}}$ is the absorbance of the blank (in the case of phosphate buffer, $\left.A_{\mathrm{b}}=0.09\right)$.

The $\mathrm{IC}_{50}$ value is defined as the concentration of sample able to transform $50 \%$ of $\mathrm{ABTS}^{+}$to $\mathrm{ABTS}^{+}$, i.e. when the absorbance of the remaining radical $\left(A_{\mathrm{r}}-A_{\mathrm{b}}\right)$ was the same than that of the scavenged radical $\left(A_{\mathrm{i}}-A_{\mathrm{r}}\right)$. Thus, $\log \left(\mathrm{IC}_{50}\right)$ corresponds to the $x$ intercept of the curve:

$$
\log \left(A_{\mathrm{r}}-A_{\mathrm{b}}\right) /\left(A_{\mathrm{i}}-A_{\mathrm{r}}\right) \text { vs. } \log [\text { sample }]
$$

where the concentrations of samples were expressed in micromolar for gallic acid and Trolox, micromolar eq. $\mathrm{NH}_{2}$ for the peptide fractions and milligrams per liter eq. BSA for the protein fractions.

The Trolox-equivalent antioxidant capacity (TEAC) measures the free radical scavenging capacity of a given substance, as compared to the standard, Trolox. The TEAC is the ratio of the slope of the plot of activity versus concentration of the given substance over the slope of the plot of Trolox (Re et al. 1999). The TEAC is expressed as micromoles Trolox equivalent (TE) per milligram protein in the case of CP, CWP and MP, or micromoles TE per micromole eq. $\mathrm{NH}_{2}$ in the case of the hydrolysates. Student's $t$ tests were also performed on data to assess differences between the TEAC values of undigested samples CP and CWP compared with MP and those of digested ones with MP hydrolysate, and differences were considered significant when $p<0.05$.

\subsection{Determination of the ACE-inhibitory activity}

The ACE-inhibitory activity was determined according to Tauzin et al. (2002) with minor modifications. A volume of $20 \mu \mathrm{L}$ of ACE from rabbit lung (3.33 U.L ${ }^{-1}$; SigmaAldrich) was added to $100 \mu \mathrm{L}$ of $4.5 \mathrm{mmol}^{-1} \mathrm{~L}^{-1}$ hippuryl-L-histidyl-L-leucine (HHL; Sigma-Aldrich) and $30 \mu \mathrm{L}$ of $50 \mathrm{mmol} . \mathrm{L}^{-1} 2$-(cyclohexylamino)ethanesulfonic acid buffer containing $300 \mathrm{mmol} . \mathrm{L}^{-1} \mathrm{NaCl}$ and $5 \% \mathrm{v} / \mathrm{v}$ absolute ethanol (pH 8.3) or $30 \mu \mathrm{L}$ of samples at final concentrations of $150 \mu \mathrm{mol} . \mathrm{L}^{-1}$ eq. $\mathrm{NH}_{2}$ for peptide fractions or 
$150 \mathrm{mg} \cdot \mathrm{L}^{-1}$ for protein fractions. The mixture was incubated at $37^{\circ} \mathrm{C}$ for $1 \mathrm{~h}$. Then, the enzyme reaction was stopped by adding captopril $\left(32 \mu \mathrm{mol} . \mathrm{L}^{-1}\right)$, trisodic ethylenediaminetetraacetate at $10 \mu \mathrm{mol} . \mathrm{L}^{-1}$ and TFA at $0.13 \mathrm{~mol} . \mathrm{L}^{-1}$. After that, the released hippuric acid was quantified by RP-HPLC onto a Symmetry $\mathrm{C}_{18}$ column $(150 \times 2 \mathrm{~mm}, 5-\mu \mathrm{m}$ particle size, $10-\mathrm{nm}$ porosity; Waters Corp., Milford, MA, USA) connected to an Alliance HPLC unit 2690 (Waters) and elution was performed for $7 \mathrm{~min}$ by a linear gradient of acetonitrile in water from $13 \%$ to $50 \% \mathrm{v} / \mathrm{v}$ in the presence of $0.1 \% \mathrm{v} / \mathrm{v}$ TFA. The flow rate was $0.25 \mathrm{~mL} \cdot \mathrm{min}^{-1}$ and detection was carried out at $228 \mathrm{~nm}$ with a Waters 996 photodiode array detector. All the assays were carried out in triplicates and the percentages of inhibition, compared to the maximum activity of ACE without inhibition, were expressed as mean values \pm SD. Data were analysed by $t$ test and level of significance was considered when $p$ values were $<0.05$.

\subsection{Bacterial growth inhibition assay}

The two tested bacterial strains (Escherichia coli XL1 blue and Listeria innocua LRGIA01 strains) were cultured in brain heart infusion (BHI) broth at $30{ }^{\circ} \mathrm{C}$ as described by Kouadio et al. (2011). These two harmless strains were chosen for their similarity to foodborne pathogenic bacteria (enterohaemorrhagic E. coli and $L$. monocytogenes strains, respectively). Freeze-dried undigested and digested samples were dissolved in BHI broth and sterilised by filtration onto 0.2- $\mu \mathrm{m}$-pore-size membranes (Millipore Corp., Billerica, MA, USA). Antimicrobial tests were performed in sterile 100 wells microplates, which were incubated at $30{ }^{\circ} \mathrm{C}$ for $24 \mathrm{~h}$. Optical density at $600 \mathrm{~nm}\left(\mathrm{OD}_{600 \mathrm{~nm}}\right)$ was recorded every 15 min using a Bioscreen ${ }^{\circledR}$ plate reader (Thermo Fisher Scientific Inc., Illkirch, France). Volumes of $30 \mu \mathrm{L}$ of overnight cultures containing $1.210^{7}$ and $1.110^{7}$ colony-forming units (cfu). $\mathrm{mL}^{-1}$ of L. innocua and E. coli, respectively, were used to inoculate each well containing $270 \mu \mathrm{L}$ of BHI broth (positive controls) or $270 \mu \mathrm{L}$ of BHI broth supplemented with digested or undigested camel milk or colostrum fractions in order to obtain 10, 20 and 40 g.L f $^{-1}$ final concentrations. Triplicates were run for each concentration. In addition to the positive controls, negative controls were also included. The negative controls contained $270 \mu \mathrm{L}$ of BHI broth supplemented with undigested or digested samples in all the above mentioned concentrations and $30 \mu \mathrm{L}$ of sterile BHI broth.

The growth curves of E. coli XL1 blue and L. innocua LRGIA01 were obtained by plotting the $\mathrm{OD}_{600 \mathrm{~nm}}$ as a function of time. The percentage of inhibition of bacterial growth after $15 \mathrm{~h}$ of incubation at $30{ }^{\circ} \mathrm{C}$ was estimated by comparing $\mathrm{OD}_{600 \mathrm{~nm}}$ values measured with the mean values of the positive controls and was calculated as follows:

$$
\% \text { of inhibition }=\left[\left(\mathrm{OD}_{600 \mathrm{~nm} \text { control }}-\mathrm{OD}_{600 \mathrm{~nm} \mathrm{sample}}\right) / \mathrm{OD}_{600 \mathrm{~nm} \text { control }}\right] \times 100
$$

As all cultures were performed in triplicates, $\mathrm{OD}_{600 \mathrm{~nm}}$ values were given as mean value $\pm \mathrm{SD}$. For the antimicrobial activity assays, a $t$ test (two-samples, assuming unequal variances) was run to compare bacterial growth curves in the presence or absence of CP, CWP or MP, or their hydrolysates at different concentrations. The differences were considered significant when $p<0.05$. 


\section{Results}

\subsection{Characterisation of MP, CWP and CP and their respective hydrolysates}

The protein and peptide contents of native camel milk, colostral whey or colostrum proteins and of their hydrolysates were analysed by SDS-PAGE and RP-UHPLC, respectively.

As Lf is a well-known antimicrobial protein that is abundant in colostrum of mammals, it was used as a reference for our study in order to choose the right moment of collection of colostrum rich in Lf. Thus, the colostrum for which Lf displayed the highest band relative intensity (determined by densitometry at $633 \mathrm{~nm}$ from SDSPAGE profiles of 11 samples collected from 1 to $144 \mathrm{~h}$ post-partum; Fig. 1) corresponded to the sample collected $48 \mathrm{~h}$ post-partum.

Fractions CP (collected at $48 \mathrm{~h}$ post-partum), CWP (prepared from $48 \mathrm{~h}$ post-partum colostrum) and MP were thus prepared. Their corresponding hydrolysates (named $\mathrm{CPH}, \mathrm{CWPH}$ and MPH, respectively) were obtained by successive action of pepsin and pancreatin. Overall, the SDS-PAGE profiles (Fig. 2a) showed the absence of $\beta$ LG, the main whey protein in bovine milk (Beg et al. 1985). Little amounts of CN were observed in CWP, as they precipitated very slowly when the $\mathrm{pH}$ was lowered to 4.2 , especially in colostrum, whereas very high relative amounts of immunoglobulins $G$ (IgGs) were found in CWP. The CP fraction contained Lf, $\alpha$-lactalbumin $(\alpha$-LA) and camel serum albumin (CSA).

After hydrolysis by pepsin followed by hydrolysis by pancreatin, at least two of the initial bands remained visible on the electrophoretic profiles although they were far less intense than before the action of enzymes (Fig. 2b). They corresponded to $\alpha$-LA and to IgGs in MPH, CWPH and CPH, respectively.

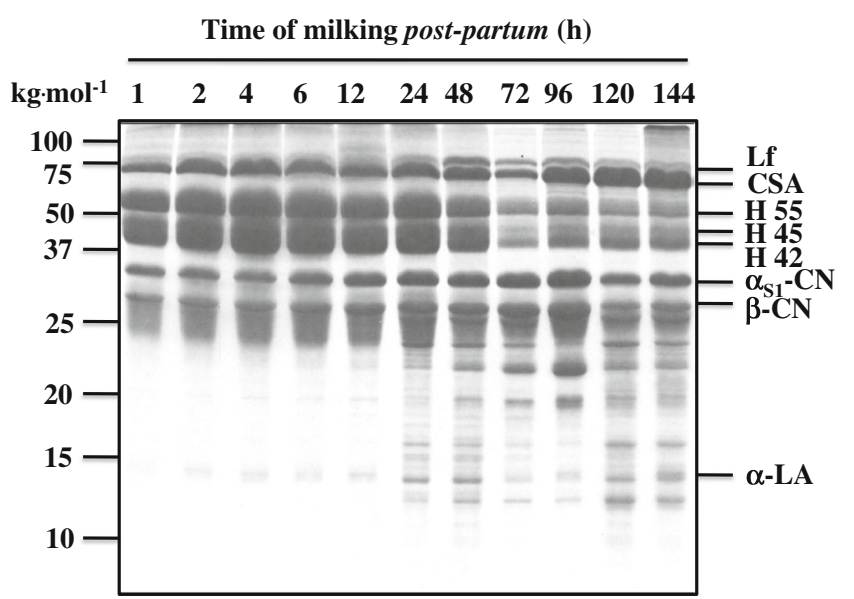

Fig. 1 SDS-PAGE profiles of total proteins from camel colostrums collected from 1 to $144 \mathrm{~h}$ post-partum. $L f$ lactoferrin, $C S A$ camel serum albumin, $H$ heavy chains of immunoglobulins $\mathrm{G}, C N$ casein, $\alpha-L A \alpha-$ lactalbumin. The H42, H45 and H55 heavy chains were identified on the electropherogram according to Lauwereys et al. (1998) and the other proteins according to the proteomic analysis of Hinz et al. (2012) 

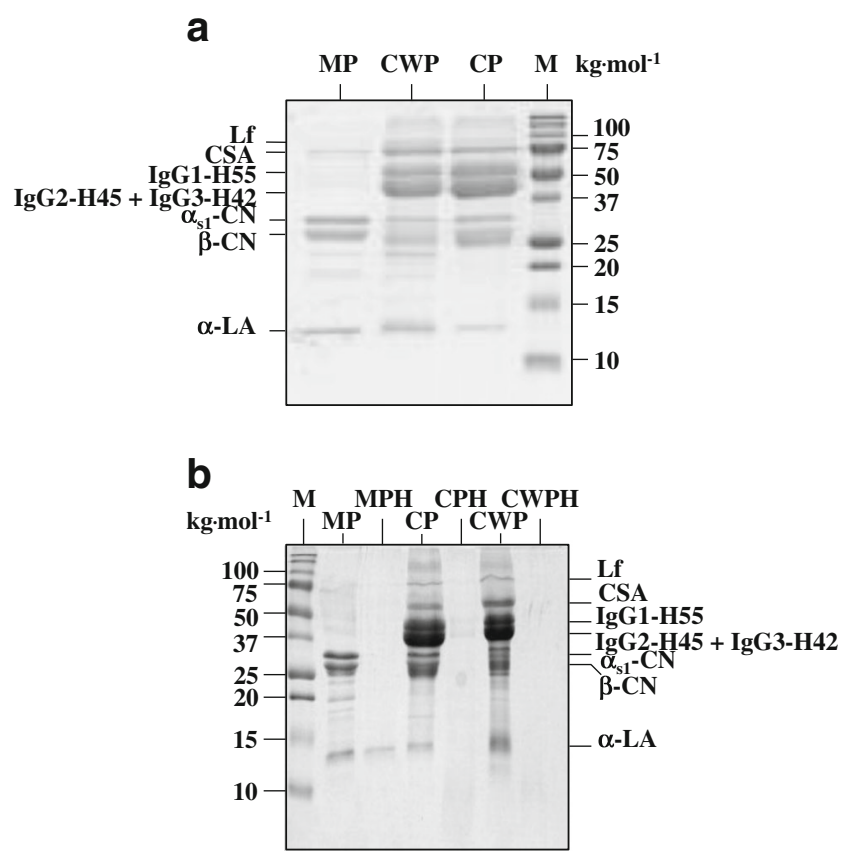

Fig. 2 a SDS-PAGE profiles of camel milk proteins $(M P)$, colostral whey proteins $(C W P)$ and colostrum proteins $(C P)$ (CWP and CP were prepared from colostrum collected $48 \mathrm{~h}$ post-partum). b SDS-PAGE profiles of the corresponding hydrolysates $\mathrm{MPH}, \mathrm{CPH}$ and $\mathrm{CWPH} . M$ molecular mass standards, $L f$ lactoferrin, $C S A$ camel serum albumin, $H$ heavy chains of immunoglobulins $\mathrm{G}$ (IgG), $C N$ casein, $\alpha-L A \alpha-$ lactalbumin. The H42, H45 and H55 heavy chains were identified on the electropherogram according to Lauwereys et al. (1998) and the other proteins according to the proteomic analysis of Hinz et al. (2012)

As most of camel milk and colostrum proteins were degraded into smaller fragments that were not detectable by SDS-PAGE analysis after the action of digestive enzymes, each protein fraction as well as their corresponding hydrolysates were characterised by RP-UHPLC analysis (Fig. 3). Three major fractions were observed after retention time of $60 \mathrm{~min}$ on the MP chromatogram, but were not present on that of MPH. The first peak corresponded to the elution of $\alpha_{\mathrm{s} 1}-\mathrm{CN}$, the second to $\alpha$-LA, the main soluble protein of milk, and the third peak corresponded to the elution of $\beta-\mathrm{CN}$, as shown by SDS-PAGE control (Fig. 3). The chromatogram was markedly modified after hydrolysis, as a number of peaks appeared between 5 and 60 min showing that the majority of proteins were hydrolysed into small peptides. The same conclusion can be drawn when comparing the chromatograms of intact colostral and colostral whey proteins with those of their respective hydrolysates.

The major peaks on chromatograms of CWP and CP were also eluted after $60 \mathrm{~min}$. However, these peaks were smaller, likely because these fractions did contain little amounts of $\mathrm{CN}$ and $\alpha$-LA comparatively to the high amounts of IgGs, the latter being poorly resolved by RP-UHPLC analysis. Particularly, the CWP profile was more complex probably due to a number of soluble proteins concentrated in whey after the acidification treatment of the colostrum. Before digestion of CP and CWP, almost no 


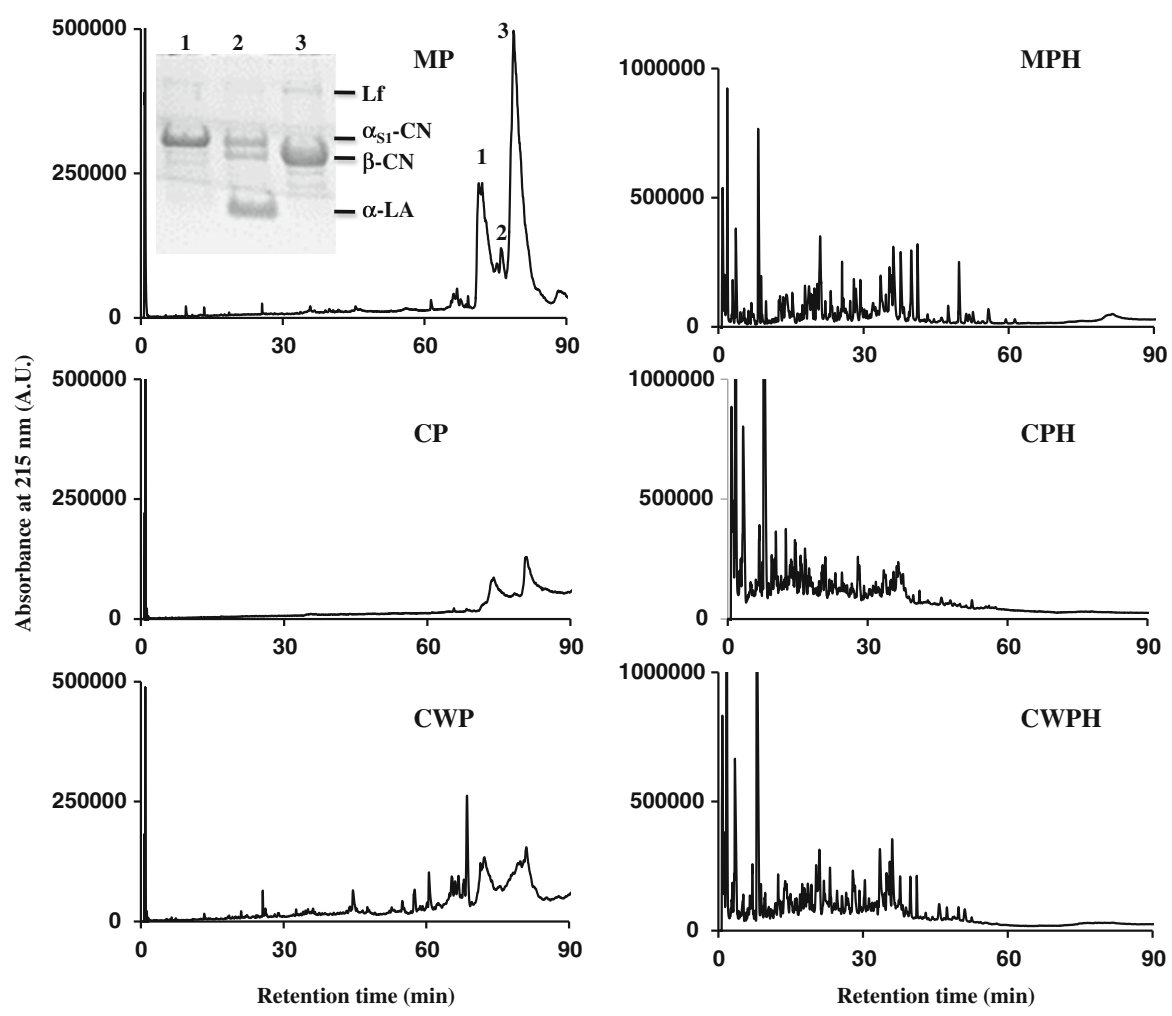

Fig. 3 RP-UHPLC chromatograms of camel milk proteins $(M P)$, colostral whey proteins $(C W P)$ and colostrum proteins $(C P)$, and their respective hydrolysates $\mathrm{MPH}, \mathrm{CWPH}$ and $\mathrm{CPH}$. Separation conditions were detailed in the "Materials and methods" section. In the case of MP, fractions 1-3 were collected and analysed by SDS-PAGE. $L f$ lactoferrin, $C N$ casein, $\alpha-L A \alpha$-lactalbumin, $A . U$. absorbance unit

peak was observed before $60 \mathrm{~min}$. This indicated that only very little amounts of peptides are present in camel milk, colostral whey or colostrum.

\subsection{Effect of enzymatic digestion}

As camel milk, colostrum and colostral whey contain bioactive proteins (antimicrobial proteins) or proteins with bioactive regions encrypted in their sequence that might be liberated by gastro-intestinal digestion (antioxidant or ACE-inhibitory peptides), the effect of an in vitro hydrolysis by digestive proteolytic enzymes on biological activities of MP, $\mathrm{CP}$ and CWP was investigated. Three biological activities that can be ascribed to proteins or their fragments were assayed in vitro: the free radical scavenging activity, the ACEinhibitory activity and the antibacterial activity. The fact that a bioactive protein can resist to the action of proteolytic enzymes, be hydrolysed into inactive fragments or even into more active fragments than the parent protein justified the interest of such a study.

\subsubsection{Radical scavenging activity}

Two potent antioxidant molecules, gallic acid and Trolox, a soluble analogue of vitamin E, were used as positive controls (Fig. 4). The TEAC value of gallic acid was 


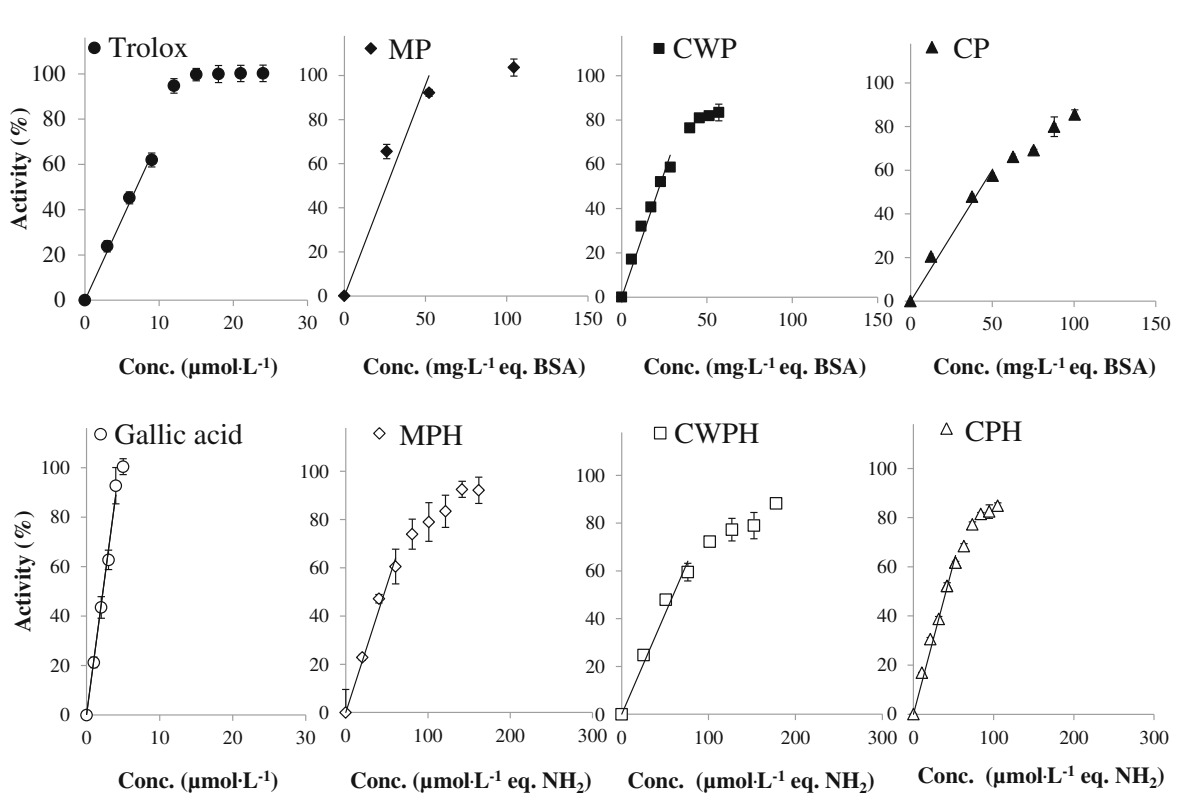

Fig. 4 ABTS radical scavenging activity of Trolox, gallic acid, camel milk proteins $(M P)$, colostral whey proteins $(C W P)$, colostrum proteins $(C P)$ and their respective hydrolysates $\mathrm{MPH}, \mathrm{CWPH}$ and $\mathrm{CPH}$

$3 \mu \mathrm{mol} \mathrm{TE} . \mu \mathrm{mol}^{-1}$, showing that gallic acid was a greater free radical scavenger than Trolox with an antioxidant power 3-fold higher, in accordance to our previous work (Sadat et al. 2011). The $\mathrm{IC}_{50}$ value of gallic acid $\left(2.0 \mu \mathrm{mol} . \mathrm{L}^{-1}\right)$ was also close to the value $\mathrm{IC}_{50}$ (2.5 $\left.\mu \mathrm{mol} . \mathrm{L}^{-1}\right)$ reported by Sadat et al. (2011) and lower than the $\mathrm{IC}_{50}$ of Trolox (6.5 $\mu \mathrm{mol} . \mathrm{L}^{-1}$ in the present study and $5.6 \mu \mathrm{mol} . \mathrm{L}^{-1}$ in the study of Sadat et al. 2011).

The ABTS-scavenging capacities of MP, CWP and CP as well as their respective hydrolysates are reported in Fig. 4 and the $\mathrm{IC}_{50}$ and TEAC values in Table 1. Among the three protein fractions, CWP exhibited a higher activity with TEAC ca. 2-fold higher than that of $\mathrm{CP}$ and $\mathrm{IC}_{50}$ ca. 2-fold lower than the $\mathrm{IC}_{50}$ of $\mathrm{CP}$. The antiradical scavenging power of MP was intermediate between those of $\mathrm{CP}$ and CWP. After digestion by pepsin and pancreatin, $\mathrm{CPH}$ that was generated from the lowest active fraction, $\mathrm{CP}$, displayed similar $\mathrm{IC}_{50}$ and similar TEAC to $\mathrm{MPH}$ and $\mathrm{CWPH}$, showing that enzymatic hydrolysis generated peptides with radical scavenging properties.

Table 1 Radical scavenging activity (TEAC and $\mathrm{IC}_{50}$ ) of camel milk proteins (MP), colostral whey proteins (CWP), colostrum proteins (CP) and their respective hydrolysates

\begin{tabular}{|c|c|c|c|}
\hline Sample & TEAC & $p$ value & $\mathrm{IC}_{50}$ \\
\hline & $\mu \mathrm{mol}$ TE. $\mathrm{mg}^{-1}$ protein & & mg. $\mathrm{L}^{-1}$ eq. $\mathrm{BSA}$ \\
\hline MP & $0.26 \pm 0.03$ & - & 24.7 \\
\hline CWP & $0.31 \pm 0.08$ & 0.012 & 19.4 \\
\hline \multirow[t]{2}{*}{$\mathrm{CP}$} & $0.16 \pm 0.04$ & 0.025 & 36.1 \\
\hline & $\mu \mathrm{mol}$ TE. $\mu \mathrm{mol}^{-1}$ eq. $\mathrm{NH}_{2}$ & & $\mu \mathrm{mol} . \mathrm{L}^{-1}$ eq. $\mathrm{NH}_{2}$ \\
\hline $\mathrm{MPH}$ & $0.15 \pm 0.03$ & - & 43.4 \\
\hline CWPH & $0.11 \pm 0.02$ & 0.870 & 54.3 \\
\hline $\mathrm{CPH}$ & $0.17 \pm 0.05$ & 0.320 & 35.6 \\
\hline
\end{tabular}


Nevertheless, the radical scavenging activities of the camel milk and colostrum hydrolysates remained low comparatively to that of Trolox (Table 1).

\subsubsection{ACE-inhibitory activity}

The in vitro ACE-inhibitory activity of $\mathrm{MP}, \mathrm{CWP}$, and $\mathrm{CP}$ and their respective hydrolysates was measured and the percentages of inhibition of ACE are given in Table 2. ACE is namely inhibited by different source of peptides. As expected, MP, CWP and CP which have low peptides content (as observed by RP-UHPLC analysis) did not significantly inhibit ACE activity. However, the ACE-inhibitory activity of these protein fractions was enhanced after their enzymatic digestion, suggesting that ACE-inhibitory peptides corresponding to camel milk and colostrum protein fragments have been released.

\subsubsection{Antimicrobial activity}

The CP, CWP and MP fractions and their respective enzymatic hydrolysates were screened for antimicrobial activities against $E$. coli XL1 blue and L. innocua LRGIA 01. Characteristic L. innocua growth curves in the presence of CP and CPH are presented in Fig. 5. The respective percentages of inhibition of the growth of the two bacterial strains are presented in Table 3. The results obtained indicate that $\mathrm{CP}$ exhibits a higher antimicrobial activity than CWP and MP. After enzymatic hydrolysis, CWPH still exhibited an antimicrobial activity indicating that either antimicrobial proteins resisted to the action of proteolytic enzymes or that new antimicrobial fragments of camel colostrum whey proteins might have been released by their action. Both $\mathrm{CP}$ and CPH significantly inhibited $E$. coli XL1 blue strain growth. Interestingly, even at a low concentration (i.e. 10 g. $\mathrm{L}^{-1}$ ), CPH significantly inhibited E. coli growth. As reported in Table 3, CPH also significantly inhibited L. innocua LRGIA 01 growth.

\subsubsection{Peptides identification}

Peptides present in $\mathrm{CPH}$, the hydrolysate displaying the highest bioactivities among the fractions tested, were identified by LC/nESI-MS/MS. Among the 181 peptides identified in the present work (data not shown), 25 peptides presented sequence homology with casein fragments reported to possess various biological activities including ACEinhibitory and free radical scavenging activities (Table 4).

Table 2 ACE-inhibitory activity of camel milk proteins (MP), colostral whey proteins (CWP), colostrum proteins $(\mathrm{CP})$ tested at $150 \mathrm{mg} . \mathrm{L}^{-1}$ and their respective hydrolysates tested at $150 \mu \mathrm{mol} . \mathrm{L}^{-1}$ eq. $\mathrm{NH}_{2}$

\begin{tabular}{llll}
\hline Undigested/digested sample & \multicolumn{2}{l}{ ACE inhibition (\%) } & $p$ value \\
\cline { 2 - 4 } & Undigested samples & Digested samples & \\
\hline $\mathrm{MP} / \mathrm{MPH}$ & 0 & $17 \pm 1$ & $<0.001$ \\
$\mathrm{CWP} / \mathrm{CWPH}$ & 0 & $9 \pm 3$ & 0.220 \\
$\mathrm{CP} / \mathrm{CPH}$ & $2 \pm 1$ & $18 \pm 4$ & 0.009 \\
\hline
\end{tabular}




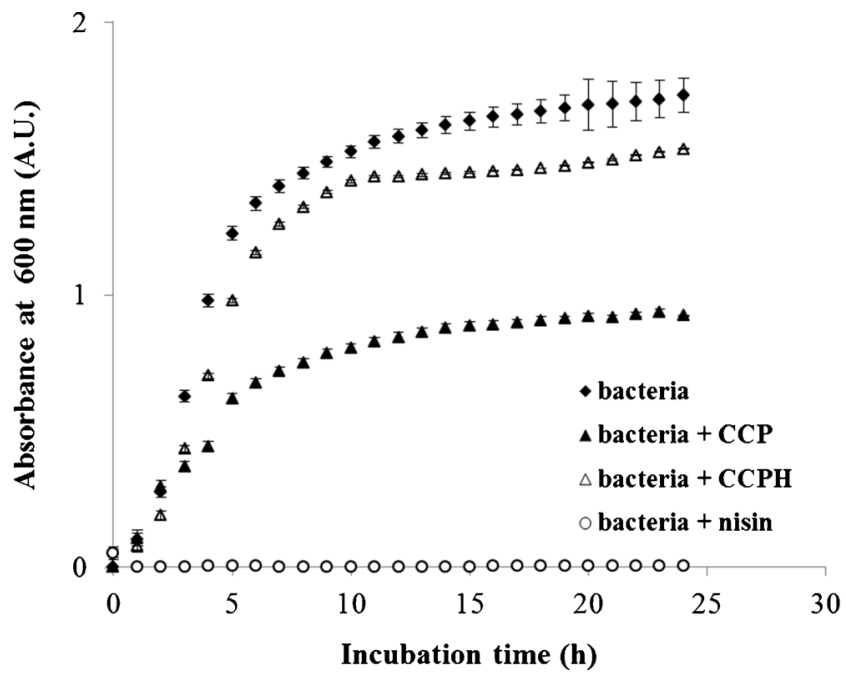

Fig. 5 Growth curves at $30{ }^{\circ} \mathrm{C}$ of $L$. innocua LRGIA01 in BHI broth in the presence of 40 g.L $\mathrm{L}^{-1}$ of CP or 10 g.L $\mathrm{L}^{-1}$ of CPH. Listeria growth was totally inhibited by nisin $\left(2,400 \mathrm{IU} \cdot \mathrm{mL}^{-1}\right)$ used as positive control

\section{Discussion}

4.1 Effect of hydrolysis by pepsin and pancreatin on camel colostral, colostral whey and milk proteins

Electropherograms and RP-UHPLC chromatograms of camel milk and colostrum proteins were consistent with previous studies regarding their respective compositions: colostrum contained far less CNs than milk and a high amount of IgGs, especially IgG2 and IgG3 (ca. 58 g.L $\mathrm{L}^{-1} 1 \mathrm{~h}$ post-partum, but not less than ca. 12 g.L $\mathrm{L}^{-1} 48 \mathrm{~h}$ post-partum; El Hatmi et al. 2007). The other soluble proteins detected by SDS-PAGE in colostrum of the camels from our experimental herd had been assayed by immunological method in a previous study: at first milking, it contained ca. 2.2 g.L $\mathrm{L}^{-1}$ of $\alpha$-LA, ca. 1.2 g.L $\mathrm{L}^{-1}$ of Lf and ca. 8.5 g.L L $^{-1}$ of CSA (El Hatmi et al. 2006). Before 60 -min elution time, no peaks and only a few peaks were present on RP-UHPLC chromatograms of camel

Table 3 Inhibition (\%) of E. coli XL1 blue and L. innocua LRGIA 01 growth by camel milk proteins (MP), colostral whey proteins (CWP), colostrum proteins (CP), colostral whey proteins hydrolysates $(\mathrm{CWPH})$ and colostrum proteins hydrolysates $(\mathrm{CPH})$ after incubation for $15 \mathrm{~h}$ at $30^{\circ} \mathrm{C}$ in $\mathrm{BHI}$ broth

\begin{tabular}{llllll}
\hline Sample & Conc. $\left(\mathrm{g} . \mathrm{L}^{-1}\right)$ & E. coli & $p$ value & L. innocua & $p$ value \\
\hline MP & 20 & $4.00 \pm 0.53$ & 0.007 & $7.90 \pm 0.84$ & 0.006 \\
& 40 & $9.80 \pm 0.42$ & $<0.001$ & $12.90 \pm 1.11$ & $<0.001$ \\
CWP & 40 & $22.00 \pm 1.53$ & $<0.001$ & $16.00 \pm 1.04$ & 0.001 \\
CP & 20 & $62.50 \pm 5.75$ & $<0.001$ & $26.70 \pm 1.2$ & $<0.001$ \\
& 40 & $62.00 \pm 3.92$ & $<0.001$ & $48.30 \pm 3.03$ & $<0.001$ \\
CWPH & 10 & $9.00 \pm 0.45$ & 0.05 & $11.10 \pm 0.52$ & 0.873 \\
CPH & 10 & $29.00 \pm 3.28$ & $<0.001$ & $15.40 \pm 1.28$ & 0.007 \\
\hline
\end{tabular}




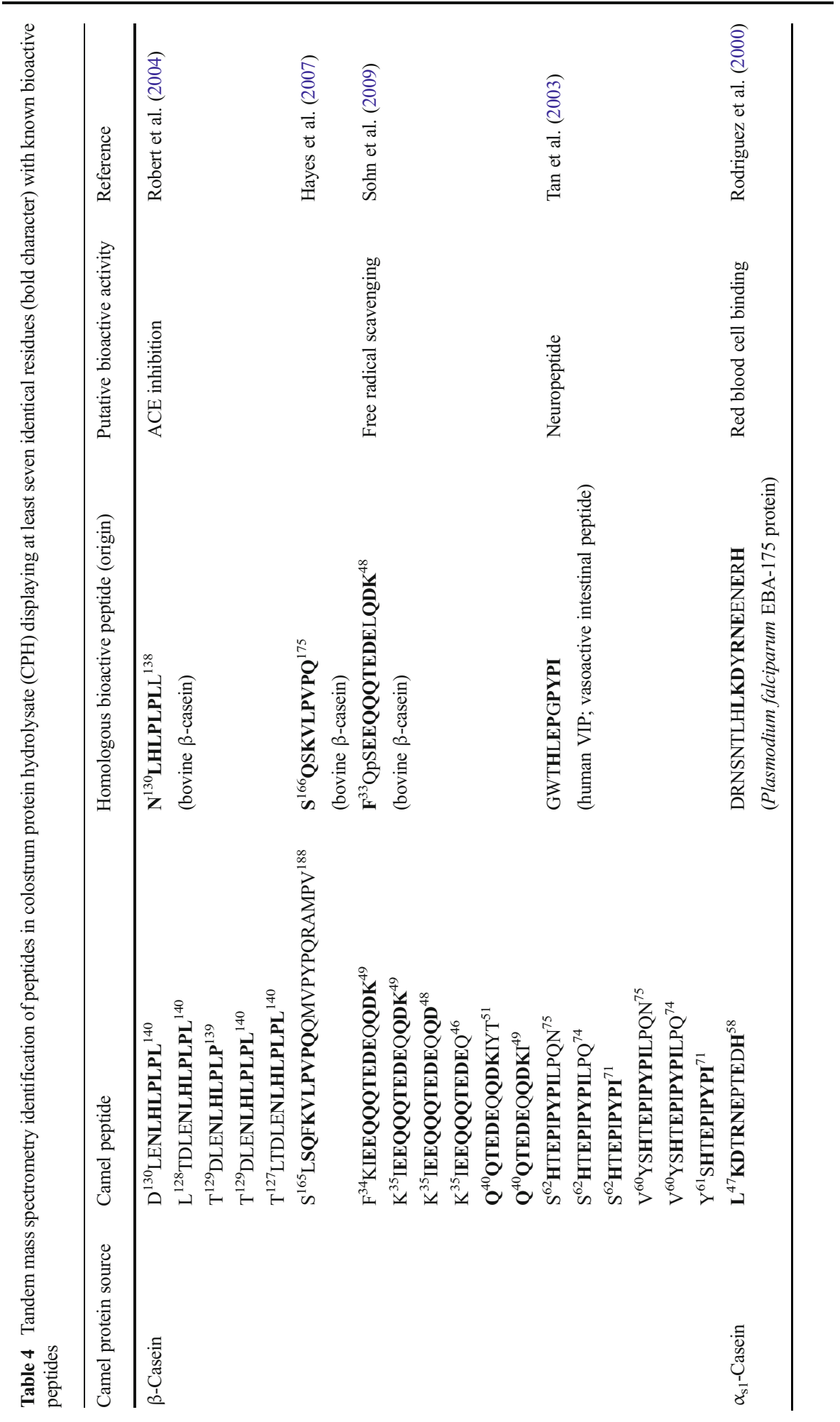

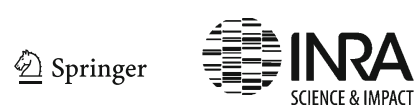




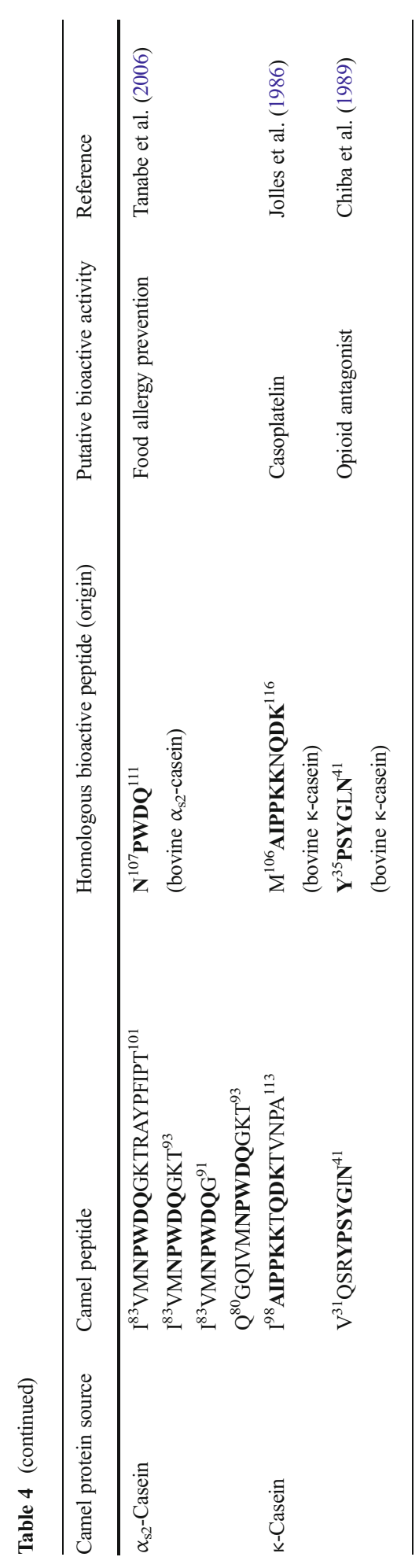


colostrum and milk proteins, respectively. This was consistent with the fact that nonprotein nitrogen (NPN), including peptides and free aminoacids, in camel colostrum and milk is far lower than protein nitrogen: the respective NPN/TN (total nitrogen) ratios of camel colostrum and milk reported in the literature were $27 \mathrm{~g} . \mathrm{kg}^{-1}$ at $2 \mathrm{~h}$ postpartum (Zhang et al. 2005) or $37{\mathrm{~g} . \mathrm{kg}^{-1}}^{-1}$ at first milking (El Hatmi et al. 2007) and 111 g. $\mathrm{kg}^{-1}$ (Shamsia, 2009), respectively.

After hydrolysis by pepsin and pancreatin, only $\alpha$-LA and IgGs bands were still visible on SDS-PAGE electropherograms. Other proteins were hydrolysed into fragments which were detected by RP-UHPLC but not by SDS-PAGE, suggesting thus that most of these fragments were low molecular mass fragments. Since $\alpha$-LA and IgG electrophoretic bands were less intense than before the action of digestive enzymes, this suggests that they are also hydrolysed into low molecular mass fragments but likely more slowly than other milk proteins. These soluble camel milk and colostrum proteins have already been reported to be more resistant toward proteolysis (Holt et al. 2003; Salami et al. 2008, 2009).

\subsection{Effect of digestive enzymes on camel colostral, colostral whey and milk} bioactivities

The radical scavenging, the ACE-inhibitory and antibacterial activities of camel milk, colostrum and colostral whey proteins were assayed in vitro before and after hydrolysis by digestive enzymes.

Although $\alpha$-LAs of bovine milk ( $\mathrm{IC}_{50}$ of $40 \mu \mathrm{mol} . \mathrm{L}^{-1}$ according to Sadat et al. 2011) and camel milk (TEAC of $30 \mu \mathrm{mol} . \mathrm{L}^{-1}$ according to Salami et al. 2009) possess strong radical scavenging activities, comparable to that of Trolox, the remarkable antioxidant properties of the camel $\alpha$-LA were not observed in the present work, probably because IgG concentrations in $\mathrm{CP}$ as well as in CWP were far higher than corresponding $\alpha$-LA concentrations: IgGs would have limited their antioxidant activity. MP contained the highest relative amount of caseins (CNs) comparatively to CWP and CP (Fig. 2). Particularly in bovine milk, the CNs have been extensively investigated, as they are a source of antioxidant peptides obtained either by enzymatic hydrolysis or by fermentation. Indeed, radical scavenging peptides corresponding to $\beta-\mathrm{CN}$ (Kansci et al. 2004) and $\alpha_{\mathrm{s} 1}-\mathrm{CN}$ (Suetsuna et al. 2000) fragments have been identified. The increase of radical scavenging activity of camel milk and colostral proteins after their hydrolysis by digestive proteolytic enzymes is consistent with the observation of Salami et al. (2010) showing that the capability of camel milk whey proteins to scavenge free radicals was increased after hydrolysis by proteinase K. In the present work, the increase of radical scavenging activity of camel colostrum proteins after the action of digestive enzymes was unveiled. This was in agreement with the presence of peptides displaying a strong identity with the bovine 33-48 $\beta$-caseinopeptide known to form stable radical (Table 4).

To our knowledge, the only studies reporting the ACE-inhibitory activity of peptides generated from camel milk proteins concerned caseins. In a former study, one ACEinhibitory peptide, $\mathrm{K}-\mathrm{CN}(107-115)$, has been identified from fermented camel milk prepared with Lactobacillus helveticus 130B4 (Quan et al. 2008). Recently, Salami et al. (2011) have shown that a peptic hydrolysate of purified camel $\beta-\mathrm{CN}$ displayed a high ACE-inhibitory activity; this is consistent with the increase of camel milk proteins ACE-inhibitory activity after hydrolysis by pepsin followed by pancreatin observed in 
the present study. In this study, we have shown that the digestive proteolytic enzymes also generated ACE-inhibitory fragments from camel colostrum proteins. Some peptides generated by pepsin and pancreatin action on colostrum proteins presented strong sequence similarity with known ACE inhibitors and therefore might have an ACE inhibitory action, putatively (Table 4).

The antibacterial activity of camel milk and colostrum proteins was tested with a Gram-positive (L. innocua) and a Gram-negative (E. coli) bacterial strain. Colostral proteins had a higher antibacterial activity against both bacteria than colostral whey proteins and milk proteins. This ranking was consistent with the observations of Benkerroum et al. (2004) and El-Agamy et al. (1992) who also noted an antimicrobial effect against Gram-positive and Gram-negative bacteria, including E. coli. Camel CPH still significantly inhibited the growth of $E$. coli and to a lesser extent $L$. innocua. This suggests that fragments of proteins with a higher antimicrobial activity than that of antimicrobial proteins present in camel colostrum could be released following the hydrolysis of camel colostral proteins by digestive enzymes. Salami et al. (2010) recently reported that a limited hydrolysis by proteinase $\mathrm{K}$ of whole camel milk whey proteins significantly enhanced their inhibition of $E$. coli growth in Luria-Bertani broth. However, a limited hydrolysis by either trypsin or chymotrypsin did not significantly enhance their antimicrobial activity. Since camel colostrum is rich in Lf, the possibility that proteolytic enzymes could release fragments of camel Lf with a higher antimicrobial activity than intact Lf should now be investigated. As reported by Tomita et al. (2009), a limited hydrolysis of bovine Lf by pepsin significantly increases the inhibition of $E$. coli growth, namely because Lf fragments with a higher antimicrobial activity than intact Lf, such as lactoferricin, are released.

\section{Conclusions}

Following hydrolysis by pepsin and pancreatin to mimic digestion of camel milk, colostral whey and colostrum proteins, most of the present proteins were hydrolysed into peptides. Interestingly, the radical scavenging and the ACE-inhibitory activities of the hydrolysates increased following digestion, showing that bioactive peptides were released by digestion of camel milk and colostrum proteins.

Regarding antimicrobial activity, it is of interest to observe that camel milk, colostral whey and colostrum proteins still inhibited L. innocua LRGIA01 and E. coli XL1 blue growth after the action of digestive enzymes. These antimicrobial activities are namely due to proteins such as Lf. In the case of colostrum, the E. coli growth inhibitory activity did not decrease following enzymatic digestion: this strongly suggested that antimicrobial fragments of colostrum proteins having a higher activity than native Lf were released. As a consequence, ongoing work concerns the identification of fragments of camel Lf, which could exhibit a higher antimicrobial activity than intact camel Lf. Although these preliminary in vitro assay results were promising, the biological activities have also to be studied by other approaches, as they cannot be extrapolated in vivo. For instance, in vitro digestion experiments should be performed with more complex digestion protocols better mimicking human digestion by either adults or newborn infants and/or mimicking different physiological situations. 
Acknowledgements The authors would like to acknowledge the Ministère des Affaires Etrangères (France) for supporting Dr Halima El Hatmi's stays (SSHN grants) in BioDyMIA (Université Lyon 1, France) and UR AFPA (Université de Lorraine, France) laboratories. The authors also thank IRA (Medenine, Tunisia) and University of Gabes (Tunisia) for supporting Mrs Zeineb Jrad's stay in BioDyMIA laboratory, Dr Faïza Zidane (UR AFPA) for her good advices in the ACE-inhibitory activity assays and Mrs Claire Soligot-Hognon (UR AFPA) for technical assistance in UHPLC.

\section{References}

Abd El-Gawad IA, El-Sayed EM, Mahfouz MB, Abd El-Salam AM (1996) Changes of lactoferrin concentration in colostrum and milk from different species. Egypt J Dairy Sci 24:297-308

Beg OU, Bahr-Lindström HV, Zaidi ZH, Jörnvall H (1985) The primary structure of $\alpha$-lactalbumin from camel milk. Eur J Biochem 147:233-239

Benkerroum N, Makkaoui B, Bennani N, Kamal H (2004) Antimicrobial activity of camel's milk against pathogenic strains of Escherichia coli and Listeria monocytogenes. Int J Dairy Technol 57:39-43

Chiba H, Tani F, Yoshikawa M (1989) Opioid antagonist peptides derived from K-casein. J Dairy Res 56:363366

El-Agamy EI, Ruppanner R, Ismail A, Champagne CP, Assaf R (1992) Antibacterial and antiviral activity of camel milk proteins. J Dairy Res 59:169-175

El Hatmi H, Levieux A, Levieux D (2006) Camel (Camelus dromedarius) immunoglobulin G, $\alpha$-lactalbumin, serum albumin and lactoferrin in colostrum and milk during the early post partum period. J Dairy Res 73 : 288-293

El Hatmi H, Girardet JM, Gaillard JL, Yahyaoui MH, Attia H (2007) Characterisation of whey proteins of camel (Camelus dromedarius) milk and colostrum. Small Rumin Res 70:267-271

El Hatmi H (2007) Lait et colostrum camelin: évolution de la physico-chimie et de la fraction protéique soluble en fonction du stade de lactation. [Camel milk and colostrum: monitoring of physico-chemical properties and of the water-soluble proteins as a function of milking stage] $\mathrm{PhD}$ thesis, University of Sfax, Tunisia, pp 139

Farah Z (1993) Composition and characteristics of camel milk. J Dairy Res 60:603-626

Farnaud S, Evans RW (2003) Lactoferrin - a multifunctional protein with antimicrobial properties. Mol Immunol 40:395-405

Frister H, Meisel H, Schlimme E (1988) OPA method modified by use of N, N-dimethyl-2mercaptoethylammonium chloride as thiol component. Fresenius J Anal Chem 330:631-633

Hayes M, Stanton C, Slattery H, O'Sullivan O, Hill C, Fitzgerald GF, Ross RP (2007) Casein fermentate of Lactobacillus animalis DPC6134 contains a range of novel propeptide angiotensin-converting enzyme inhibitors. Appl Environ Microbiol 73:4658-4667

Hernandez-Ledesma B, Amigo L, Ramos M, Recio I (2004) Release of angiotensin converting enzymeinhibitory peptides by simulated gastrointestinal digestion of infant formulas. Int Dairy J 14:889-898

Hernández-Ledesma B, Contreras MM, Recio I (2011) Antihypertensive peptides: production, bioavailability and incorporation into foods. Adv Colloid Interface Sci 165:23-35

Hinz K, O’Connor PM, Huppertz T, Ross RP, Kelly AL (2012) Comparison of the principal proteins in bovine, caprine, buffalo, equine and camel milk. J Dairy Res 79:185-191

Holt LJ, Herring C, Jespens LS, Woolven BP, Tomlinson IM (2003) Domain antibodies: proteins for therapy. Trends Biotechnol 21:484-490

Jäkälä P, Vappatalo H (2010) Antihypertensive peptides from milk proteins. Pharmaceuticals 3:251-272

Jolles P, Levy-Toledano S, Fiat AM, Soria C, Gillessen D, Thomaidis A, Dunn FW, Caen JP (1986) Analogy between fibrinogen and casein. Effect of an undecapeptide isolated from $\mathrm{K}$-casein on platelet function. Eur J Biochem 158:379-382

Kansci G, Genot C, Meynier A, Gaucheron F, Chobert JM (2004) $\beta$-Caseinophosphopeptide (f1-25) confers on $\beta$-casein tryptic hydrolysate an antioxidant activity during iron/ascorbate-induced oxidation of liposomes. Lait 84:449-462

Kappeler SR, Heuberger C, Farah Z, Puhan Z (2004) Expression of the peptidoglycan recognition protein, PGRP, in the lactating mammary gland. J Dairy Sci 87:2660-2668

Korhonen H, Pihlanto A (2007) Technological options for the production of health-promoting proteins and peptides derived from milk and colostrum. Curr Pharm Design 13:829-843 
Kouadio IA, Oulahal N, Nguyen-Thi P, Adt I, Degraeve P (2011) Study of the antimicrobial activities of Solanum indicum ssp. Distichum (Shumach and Thonning 1827) fruits ("gnangnan" berries) from a tropical humid zone (Côte d'Ivoire). Int J Biol Chem Sci 5:1190-1200

$\mathrm{Ku} \mathrm{HK}$, Lim HM, Oh KH, Yang HJ, Jeong JS, Kim SK (2013) Interpretation of protein quantitation using the Bradford assay: comparison with two calculation models. Anal Biochem 434:178-180

Laemmli UK, Favre M (1973) Maturation of the head of bacteriophage T4. I. DNA packaging events. J Mol Biol 80:575-579

Lauwereys M, Ghahroudi MA, Desmyter A, Kinne J, Holzer W, De Genst E, Wyns L, Muyldermans S (1998) Potent enzyme inhibitors derived from dromedary heavy-chain antibodies. EMBO J 17:35123520

Ochirkhuyag B, Chobert J-M, Dalgalarrondo M, Choiset IY, Haertlé T (1998) Characterization of whey proteins from Mongolian yak, khainak, and bactrian camel. J Food Biochem 22:105-124

Parrot S, Degraeve P, Curia C, Martial-Gros A (2003) In vitro study on digestion of peptides in Emmental cheese: analytical evaluation and influence on angiotensin I converting enzyme inhibitory peptides. Nahrung/Food 47:87-94

Quan S, Tsuda H, Miyamoto T (2008) Angiotensin I-converting enzyme inhibitory peptides in skim milk fermented with Lactobacillus helveticus 130B4 from camel milk in Inner Mongolia, China. J Sci Food Agric 88:2688-2692

Qureshi TM, Vegarud GE, Abrahamsen RK, Skeie S (2013) Angiotensin I-converting enzyme-inhibitory activity of the Norwegian autochthonous cheeses Gamalost and Norvegia after in vitro human gastrointestinal digestion. J Dairy Sci 96:838-853

Re R, Pelligrini N, Proteggente A, Pannala A, Yang M, Price-Evans C (1999) Antioxidant activity applying an improved ABTS radical cation decolourisation assay. Free Radical Biol Med 26:1231-1237

Ricci I, Artacho R, Ollala M (2010) Milk protein peptides with angiotensin I-converting enzyme inhibitory (ACEI) activity. Crit Rev Food Sci Nutr 50:390-402

Robert V, Auchere D, Boudier JF, Gaillard JL, Monnet V, Tauzin J, Grynberg A (2004) Identification of angiotensin-I-converting enzyme inhibitory peptides derived from sodium caseinate hydrolysates produced by Lactobacillus helveticus NCC 2765. J Agric Food Chem 52:6923-6931

Rodriguez LE, Urquiza M, Ocampo M, Suarez J, Curtidor H, Guzman F, Vargas LE, Triviños M, Rosas M, Patarroyo ME (2000) Plasmodium falciparum EBA-175 kDa protein peptides which bind to human red blood cells. Parasitology 120:225-235

Rousseau-Ralliard D, Goirand F, Tardivel S, Lucas A, Algaron F, Mollé D, Robert MC, Razaname A, Mutter M, Juillerat MA (2011) Inhibitory effect of $\alpha_{\mathrm{s} 1^{-}}$and $\alpha_{\mathrm{s} 2}$-casein hydrolysates on angiotensin I-converting enzyme in human endothelial cells in vitro, rat aortic tissue ex vivo, and renovascular hypertensive rats in vivo. J Dairy Sci 93:2906-2921

Sadat L, Cakir-Kiefer C, N'Negue MA, Gaillard JL, Girardet JM, Miclo L (2011) Isolation and identification of antioxidant peptides from bovine $\alpha$-lactalbumin. Int Dairy J 21:214-221

Salami M, Yousefi R, Ehsani MR, Dalgalarrondo M, Chobert JM, Haertlé T, Razavi SH, Saboury AA, Niasari-Naslaji A, Moosavi-Movahedi AA (2008) Kinetic characterization of hydrolysis of camel and bovine milk proteins by pancreatic enzymes. Int Dairy J 18:1097-1102

Salami M, Yousefi R, Ehsani MR, Razavi SH, Chobert JM, Haertlé T, Saboury AA, Atri MS, Niasari-Naslaji A, Ahmad F, Moosavi-Movahedi AA (2009) Enzymatic digestion and antioxidant activity of the native and molten globule states of $\alpha$-lactalbumin: possible significance for use in infant formula. Int Dairy J 19 : $518-523$

Salami M, Moosavi-Movahedi AA, Ehsani MR, Yousefi R, Haertlé T, Chobert JM, Razavi SH, Henrich R, Balalaie S, Ebadi SA, Pourtakdoost S, Niasari-Naslaji A (2010) Improvement of the antimicrobial and antioxidant activities of camel and bovine whey proteins by limited proteolysis. J Agric Food Chem 58: 3297-3302

Salami M, Moosavi-Movahedi AA, Moosavi-Movahedi F, Ehsani MR, Yousefi R, Fahadi M, Niasari-Naslaji A, Saboury AA, Chobert JM, Haertlé T (2011) Biological activity of camel milk casein following enzymatic digestion. J Dairy Res 78:471-487

Shamsia SM (2009) Nutritional and therapeutic properties of camel and human milks. Int J Genet Mol Biol 1: $52-58$

Sohn CH, Chung CK, Yin S, Ramachandran P, Loo JA, Beauchamp JL (2009) Probing the mechanism of electron capture and electron transfer dissociation using tags with variable electron affinity. J Am Chem Soc 131:5444-5459

Suetsuna K, Ukeda H, Ochi H (2000) Isolation and characterization of free radical scavenging activities peptides derived from casein. J Nutr Biochem 11:128-131 
Tauzin J, Miclo L, Gaillard JL (2002) Angiotensin I-converting enzyme inhibitory peptides from tryptic hydrolysate of bovine $\alpha_{\mathrm{s} 2}$-casein. FEBS Lett 531:369-374

Tan YV, Couvineau A, Van Rampelbergh J, Laburthe M (2003) Photoaffinity labeling demonstrates physical contact between vasoactive intestinal peptide and the N-terminal ectodomain of the human VPAC1 receptor. J Biol Chem 278:36531-36536

Tanabe S, Isobe N, Miyauchi E, Kobayashi S, Suzuki M, Oda M (2006) Identification of a peptide in enzymatic hydrolyzate of cheese that inhibits ovalbumin permeation in Caco-2 cells. J Agric Food Chem 54:6904-6908

Tomita M, Wakabayashi H, Shin K, Yamauchi K, Yaeshima T, Iwatsuki K (2009) Twenty-five years of research on bovine lactoferrin applications. Biochimie 91:52-55

Zhang H, Yao J, Zhao D, Liu H, Li J, Gu M (2005) Changes in chemical composition of Alxa bactrian camel milk during lactation. J Dairy Sci 88:3402-3410 